\title{
Application of Cadastral Data in the Land Acquisition Process for Flood Control Investments
}

\section{Introduction}

A cadastre system is a basic land information system based on plot records and contains three essential elements which are fundamental for proper land administration in every country: ownership, value and manner of use. A modern cadastre system serves the needs of the owner and society as regards to spatial and economic planning, tax and benefit assessment, public statistics and identification of the property in land and mortgage registers.

Floods are one of the leading global causes of death, loss of material value and earnings and, therefore one of the major causes of deteriorated social development and a potential source of poverty [6]. Until recently, Poland was considered to be a country almost free from natural threats. The summer of 1997 was crucial in making the country aware of the effects of natural disasters. A disastrous flood on the Oder River and its tributaries caused huge material losses and claimed dozens of lives [1].

In Poland, floods are mainly caused by intensive and violent precipitation and ice jams which, when combined with human interference in the environment (e.g. residential development of flood risk zones, or intensive agricultural activity carried out within their boundaries) can result in aggravating their tragic social and economic effects [9].

One of the many steps taken towards reducing the effects of floods in Poland was the Act on Specific Principles for Preparing Implementation of Investments Concerning Flood Control Structures passed in July 2010 (Dz.U. No. 143, item 963) [11]. The Special Purpose Flood Control Act simplifies the expropriation procedure concerning properties for constructing, e.g. flood banks. An investment which is a public purpose investment [10] can be initiated immediately after issuing the decision permitting its implementation.

\footnotetext{
* University of Warmia and Mazury, Department of Cadastre and Spatial Management, Olsztyn, Poland
} 
The aim of the study is to analyse the role of the property cadastre in the process of acquiring land for hydro-technical investments, mainly at the stage of preparing a decision concerning the permit for implementing a flood control construction project.

\section{Condition of the Hydro-Technical Infrastructure in Poland}

Floods are natural phenomena, related to water circulation in nature, therefore, they cannot be avoided. The damage they cause is mainly the effect of introducing human settlements and agriculture to flood lands in river valleys. Humanity seeks to handle this threat in two ways. Science has developed methods for foreseeing a flood wave approaching, which include, e.g. flood banks [7]. These are ground structures, used for passive protection of flood-threatened areas. They play a very important role in the struggle for life and possessions of people inhabiting intensively developed areas of river valleys.

Unfortunately, the present condition of flood banks is not satisfactory and requires immediate intervention. Embanking protects the land of an area of about 1.1 million located behind the bank. According to the data of the Institute for Land Reclamation and Grassland Farming, the length of flood banks is almost 8,500 km and a significant part does not comply with requirements demanded from devices of this type. Along $40 \%$ of their length, the banks require reconstruction or modernization and along $29 \%$ of their length, they are not maintained in good technical order [4].

This bad situation results from negligence in control, maintenance and repair of flood protection structures, which during a flood crisis causes [7]:

- excessive soaking through the bank and leaks on the land slope,

- soaking of the bank body and slope sliding,

- hydraulic openings near the foot of the land slope,

- washout of the water slope by waves, currents and ice passing by, posing a threat to its structure,

- soaking near the structures, cutting the flood banks or structures built into them,

- water pouring over the top of the bank.

An opportunity to change this unfavourable situation is The Special Purpose Flood Protection Act which entered into force on 8 July 2010, determining the specific principles and conditions for preparing an investment concerning construction e.g. of flood banks, as well as the amendment of 2011 of the Water Law Act of 18 July 2001 (Dz.U. of 2005, No. 239, item 2019 as amended) [12]. 
To ensure water tightness and stability of flood banks, the Water Law Act of 18 July 2001 prohibits [12]:

- driving vehicles, riding horseback or driving animals across the flood banks and along the top of the flood banks, except for places intended for this purposes;

- land cultivation, planting trees or bushes on flood banks and at the distance of less than $3 \mathrm{~m}$ from the foot of the bank on the land slope;

- digging out the flood banks, ramming poles, the placing of signs by unauthorized persons;

- performing construction work, digging wells, ponds or ditches at the distance of less than $50 \mathrm{~m}$ from the flood bank foot on the land slope;

- damaging the sod or other reinforcements of slopes and the top of the flood banks.

\section{The Property Cadastre System in the Face of a Flood Threat}

In the process of acquiring land for investments related to construction of flood protection infrastructure, what is significant is the access to various types of spatial data, the source of which is, e.g. property cadastre recording land information as regards to the actual state, without which proper land management would not be possible [5].

\subsection{Simplified Expropriation Procedure - the Special Purpose Flood Protection Act of 2010}

Reducing losses resulting from increasingly frequent floods requires both legal solutions in flood protection and undertaking proper protective investments on the threatened areas. Negligence in flood control management results, on one hand, from limited financial means, but on the other, also from the long administrative procedure required for preparing the investment. To simplify and accelerate the process of investments concerning flood control structures - e.g. bypass channels, flood polders and flood banks - the Polish parliament passed the special purpose flood protection act on 8 July 2010.

By law, the authority responsible for issuing a decision concerning a permit for investment implementation is the provincial governor, and a higher ranking authority is the minister in charge of construction, spatial order and housing. This decision is issued at the request of the investor, who, pursuant to Art. 2.2 of the Act, can only be the regional water management board, a maritime office, a province, a district, a commune or a private partner in the meaning of the Act on Public and Private Partnership of 19 December 2008 (an entrepreneur or a foreign entrepreneur). Solutions provided in the Flood Protection Act follow the example of the special purpose road act. 
Legal effects of issuing a decision concerning the permit to implement the investment are far-reaching because this decision:

- is tantamount to obtaining a decision on land development conditions or a decision on establishing the location of a public purpose investment;

- indicates the location of flood protection structures;

- approves a property division;

- on its basis, the ownership of properties is transferred to the Treasury or a local government unit by virtue of law;

- perpetual usufruct expires - if the landed property was owned by the Treasury or a local government unit and was let for perpetual usufruct;

- determines the date on which the expropriated property should be delivered, and buildings, premises and other facilities emptied;

- provides the basis for making entries in the land and mortgage register and in the property cadastre;

- provides the basis for issuing, by the provincial governor, a decision on the expiry of the perpetual administration established on the property intended for the investment and owned by the Treasury and a local government unit;

- determines the date of expiry of all lease, tenancy and lending agreements concerning the property ( 30 days as of the day on which the decision became final).

The provincial governor issues such a decision within 90 days as of submitting the application by the investor. Figure 1 presents a simplified expropriation procedure.

The provincial governor is obliged to notify the applicant as well as the owners and perpetual usufructuaries of the properties covered by the application about the procedure for initiating the proceedings for issuing a decision concerning the permit for investment implementation (in writing). This information is also published in the form of an announcement in the provincial office, offices of competent communes for the location of the investment and the commune head (mayor, president of the city) announces the initiation of the proceedings on the website of the commune office. The notification results in that properties owned by the Treasury or a local government unit covered by the application cannot be traded. Additionally, procedures aiming at issuing the decision permitting the development of the property covered by the application or permitting the implementation of a road investment are also suspended. For transferring the rights to the property which was considered necessary for flood protection investment to the Treasury or a local government unit, the owner or a perpetual usufructuary is entitled to award. The amount of the award is agreed between the investor and the previous owner, the perpetual usufructuary or the person who has a limited property right to the property. If within two months as of the day on which the decision for implementation of the investment became final the amount of award has not been determined, the award is specified by the provincial governor by way of a decision. The principles for determining the amount of award are adopted pursuant to the provisions of the Act on Property Management of 21 August 1997, with certain modifications. 


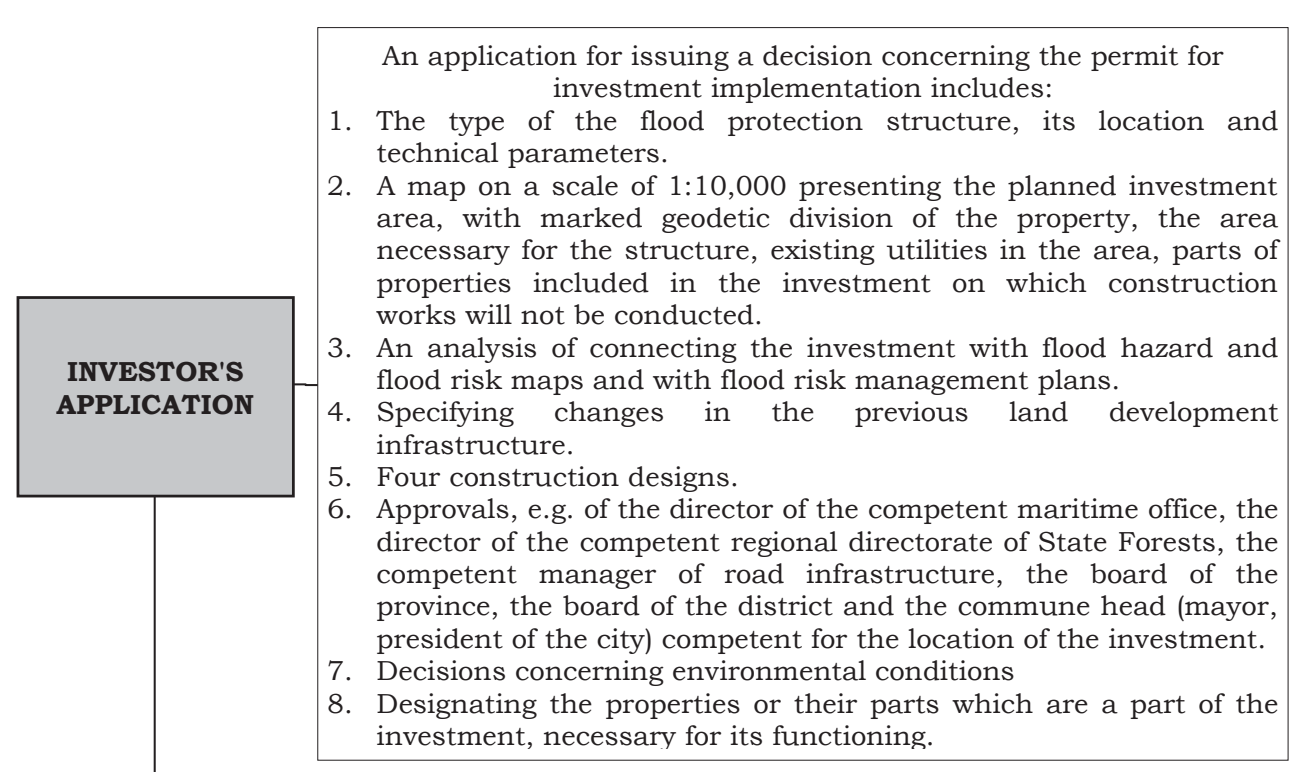
The provincial governor's notification on initiating the proceedings for issuing a decision
sent, among others, to: the applicant, the owners and the perpetual usufructuaries of the
properties covered by the application for issuing the decision at the address indicated in the
property cadastre.

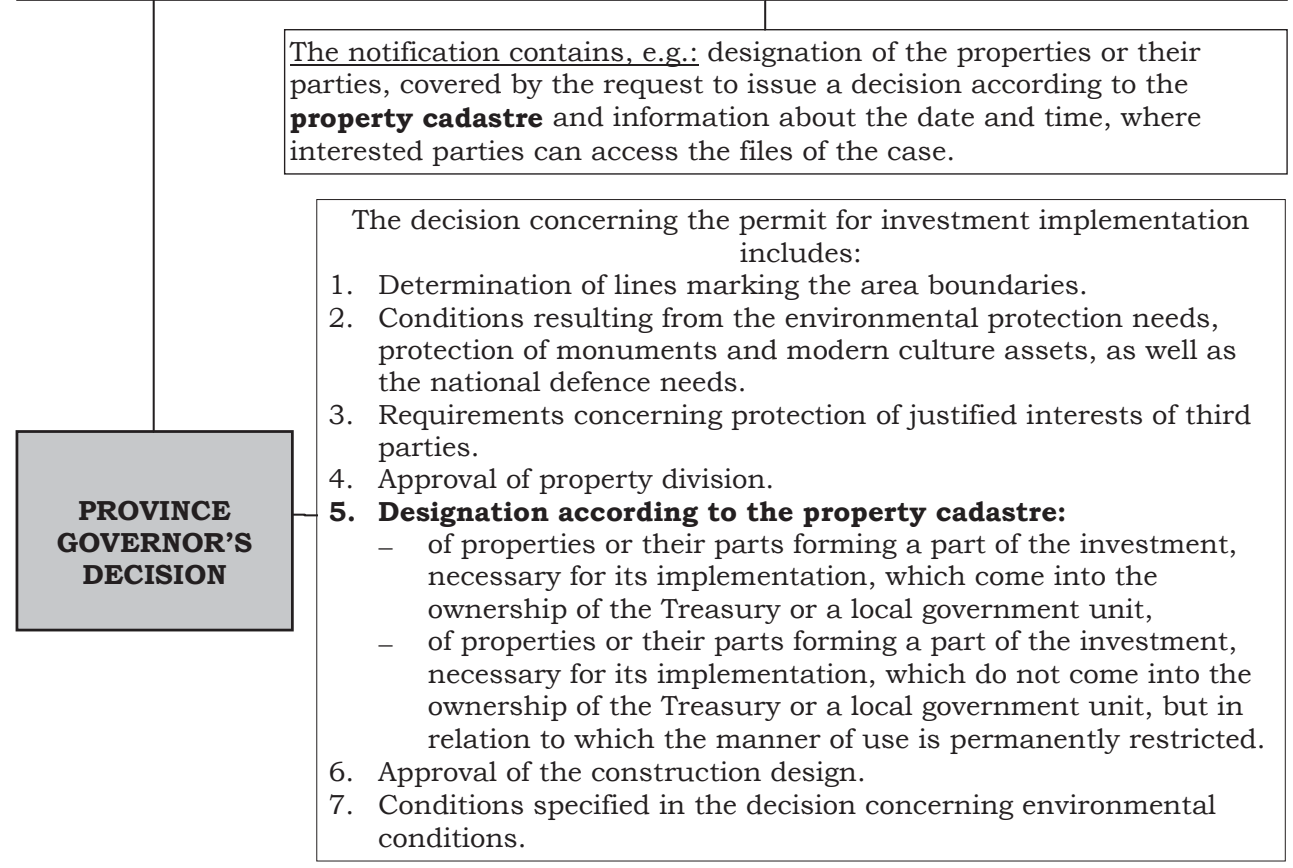

Fig. 1. Simplified expropriation procedure - the special purpose flood protection act of 2010 Source: own study on the basis of [11] 
Pursuant to Art. 21 of the Flood Protection Act, the amount of award for expropriated land and buildings is established according to the status of the property on the day of issuing the decision concerning the permit for implementation of the investment by the provincial governor and according to the value of this property on the day on which the amount of award is specified. If the property is encumbered with limited property rights, the amount of due award is reduced by the amount equal to the value of those rights. The award is also due to a creditor whose liability is secured by a mortgage on the expropriated property. In such a case, the creditor is entitled to an amount equal to the principal performance of the liability secured by a mortgage and interests secured by this mortgage. The Act also contains a provision concerning an increase of the award paid. Pursuant to Art. 21.7 of the Act, if a previous owner or a perpetual usufructuary of the property covered by the decision concerning a permit for implementation of the investment delivers this property or delivers the property and empties the premises or other facilities immediately, but not later than within 30 days as of:

- serving a notification on issuing a decision concerning the permit for investment implementation,

- serving a resolution on making a decision concerning the permit for investment implementation immediately enforceable,

- the day on which the decision concerning the permit for investment implementation became final - the amount of the award is increased by an amount equal to $5 \%$ of the value of the property or the value of perpetual usufruct rights.

If the decision concerning the permit for investment implementation relates to a property with a residential building or a building in which a residential unit has been separated, the amount of the award is increased by PLN 10,000, but only if this award is due to the previous owner or the perpetual usufructuary inhabiting this building or residential unit. The total amount of the award due cannot be higher than the value of the property or the value of the perpetual usufruct right, whereas the calculated award does not include the amount specified above, i.e. for earlier delivery of the property and PLN 10,000 for a residential unit inhabited by the owner.

If the decision concerning the permit for investment implementation concerns only a part of the property, and the other part is not suitable for previous purposes, the investor is obliged to purchase, at the request of the owner or the perpetual usufructuary of the property, for and on behalf of the Treasury or a local government unit, this part of the property. Pursuant to the Act, the investor is also entitled to purchase properties, for and on behalf of the Treasury or a local government unit, in order to exchange them for properties situated within the area of the investment or to subdivide these properties in consolidation and exchange proceedings (Art. 23.1 of the Act). 


\subsection{The Role of Property Cadastre in Acquiring Land for Flood Protection Investments}

Land information, including cadastral and topographic data, is indispensable to carry out a proper policy of land management or to plan development. The property cadastre defined in the Surveying and Cartography Law Act is a system developed by historical, political and legal conditions. As the primary system of land information being public property at the district level, it provides information to satisfy growing market needs. Its three basic elements: ownership, value and method of use form the foundations for effective land management.

The property cadastre contains a detailed data at the level of the lowest object of surface division - a record parcel, and is used for:

- spatial planning and infrastructure development;

- supporting the property taxation system;

- ensuring property rights;

- monitoring the property market;

- protecting the natural environment;

- generating statistical data.

Recently observed climatic changes resulting in floods, rainstorms, hurricanes or drought have presented a new challenge to the cadastre system: ecological catastrophes and natural disasters. Since this paper concerns the implementation of flood control investments, we shall focus on the role of cadastre data in this process.

The implementation of the investment from a geodesic point of view is related to the division of properties (belonging to various entities) and their evaluation in order to pay the due award and to purchase properties or their parts. The above-mentioned tasks will be based on the data obtained from the property cadastre.

The most important information includes:

- boundaries, areas and numbers of record parcels;

- boundaries, areas and a description of agricultural land and classification contours;

- types and location of buildings on the plot;

- information on residential premises separated in buildings;

- current data concerning the owner, perpetual usufructuaries or persons administering the land, including their current addresses of residence;

- ownership title and information on established land and mortgage registers;

- numbers of land and mortgage registers.

A well-managed cadastre should contain complete and valid data concerning the subject and the object. The district staroste is responsible for current updating of the system. It is particularly important to report and to introduce changes at the request of the interested parties, e.g. changes in the address of residence or information on the death of the co-owner. The owners very often do not report such changes to land registers, and according to the provision of the Flood Protection Act, 
"the provincial governor notifies the owner and the perpetual usufructuary of the property about initiating the proceedings for issuing a decision concerning the permit for investment implementation, sending the notification to the address specified in the property cadastre" (Art. 7.1), and "serving of the notification at the address specified in the property cadastre is effective" (Art. 7.2). The office, sending a notification or decision, does not know whether the addresses recorded in the registers are valid.

Another issue is the consistency of records in the property cadastre with entries in land and mortgage registers. Discrepancies found in plot numbers and areas or data concerning their owners create an impediment to determining and paying the award. Pursuant to the Flood Protection Act, identification (including boundaries) of the real estate property intended for investment is assumed according to the property cadastre, therefore the investor does not have to stop work if the legal status of the property differs from that found in the property cadastre. Another provision specifies that "properties or their parts, identified according to the cadastre, being a part of the investment necessary for implementation, come into the ownership of the Treasury or a local government unit (Art. 9.5a). In case of any discrepancies between the legal status and the status revealed in the cadastre, the owner can pursue its rights, but in separate proceedings. This will not stop the investment process.

The investment implementation area may include developed properties. In such a case, the established record of land and buildings - data from the register and files of buildings and premises, will allow the investor to make a preliminary evaluation of awards and the need to acquire replacement premises.

Attention should be also paid to the role of a numerical record map. The application for issuing a decision concerning a permit for investment implementation should be accompanied with maps containing property division projects. Division projects pursuant to $\S 3.1$ of the Regulation of the Council of Ministers of 7 December 2004 on the manner and mode of making property divisions are prepared on a copy of a principal map, and if there is no such a map - on a copy of a cadastre map [8]. Since the cadastral map covers the area of the entire country (unlike principal maps), it often forms the basis for preparing division projects, because we have such a cartographic base-map at our disposal.

On the basis of some examples of cadastral data importance described above, it can be noticed that the process of preparing the investment concerning flood control structure for implementation (designing, acquiring properties, construction) can be significantly improved by having access to cadastral data which is valid and consistent with the current legal status.

\section{Summary}

Floods are natural phenomena, related to water circulation in nature and, as such, cannot be avoided. The damage they cause mainly results from human 
settlements and agriculture entering flood land in river valleys [2]. Embanking is one of the methods used for reducing the tragic effect of floods and the new Special Purpose Flood Protection Act will contribute to significantly to shortening the investment process related to the prevention of disasters of this type.

Simplified procedures for flood protection investments are identical as those applicable for expropriation related to the construction of roads or to Euro 2012 investments. It is therefore not necessary to issue a separate decision either for locating the investment or for land expropriation. Both of those decisions will be included in one act. Additionally, the investor will not have to wait with commencing work for the land owner's consent to expropriation [3].

Validity, completeness, easy acquisition and compliance of the data recorded in the cadastre with both the actual and legal status of the property, the established record of buildings and premises and the consistency of the cadastral data with data recorded in land and mortgage registers all form the basis for rapid, conflict-free protection investments.

\section{References}

[1] Graniczny M., Mizerski W.: Katastrofy naturalne. PAN, Warszawa 2009.

[2] Grocki R., Eliasiewicz R.: Zagospodarowanie terenów zalewowych. Biuro Koordynacji Projektu Banku Światowego, Wrocław 2001.

[3] Jaraszek A.: Szybsze wywłaszczenia pod wały przeciwpowodziowe. [on-line:] www.gazeta prawna.pl z dnia 28.06.2010.

[4] Kaca E.: Gospodarka wodna wsi i rolnictwa. I Kongres Nauk Rolniczych "Nauka - praktyce". IMUZ, Falenty 2009.

[5] Konieczna J., Trystuła A.: Kataster nieruchomości jako podstawa systemu informacji przestrzennej wspomagającego gospodarowanie nieruchomościami. Studia i Materiały TNN, Olsztyn 2011.

[6] Pilarczyk K.: Ochrona przeciwpowodziowa w Holandii. Seminarium "Nowe podejścia do zagadnień ochrony przeciwpowodziowej", Instytut Budownictwa Wodnego PAN, Centrum Inżynierii Środowiska i Mechaniki CEM, Gdańsk 2004.

[7] Radczyk L., Żyszkowska W.: Ograniczanie skutków powodzi w skali lokalnej. Sposoby wykorzystania stref zagrożenia powodziowego. Biuro Koordynacji Projektu Banku Światowego, Wrocław 2001.

[8] Rozporządzenie Rady Ministrów z dnia 7 grudnia 2004 roku w sprawie sposobu i trybu dokonywania podziałów nieruchomości. Dz.U. z 2004 r. Nr 268, poz. 2663.

[9] Trystuła A.: Scalenia gruntów jako jeden ze sposobów ograniczenia strat powodziowych. Czasopismo Naukowe Infrastruktura i Ekologia Terenów Wiejskich, Nr 1, 2011, pp. 289-297. 
[10] Ustawa z dnia 21 sierpnia 1997 roku o gospodarce nieruchomościami. Dz.U. z 2010 r. Nr 102, poz. 651 z późn. zm.

[11] Ustawa z dnia 8 lipca 2010 roku o szczególnych zasadach przygotowania do realizacji inwestycji w zakresie budowli przeciwpowodziowych. Dz.U. z 2010 r. Nr 143, poz. 963.

[12] Ustawa z dnia 18 lipca 2001 roku - Prawo wodne. Tekst jedn. Dz.U. z 2005 r. Nr 239, poz. 2019 z późn. zm. 